\title{
İşgören Sesliliğinin Örgütsel Bağlılık Üzerindeki Etkisi: Belediye Çalışanları Üzerinde Bir Araştırma
}

\author{
Edip Örücüa ${ }^{a}$ Ömer Gizlier ${ }^{b, c}$, Gökhan Orhan Onay ${ }^{\mathrm{d}}$
}

\section{Özet}

$\mathrm{Bu}$ araştırmanın amacı işgören sesliliğinin örgütsel bağlılık üzerindeki etkisini belirlemektir. Araştırmaya gerekçe olarak literatür incelendiğinde işgören sesliliği ile örgütsel bağlılık arasındaki ilişkiyi ve etkiyi inceleyen çalışmaların kısıtlı sayıda olması gösterilebilir. Bu doğrultuda, araştırmada işgören sesliliğinin örgütsel bağlllık üzerindeki etkisinin incelenmesinin literatüre katkı sağlayacağı düşünülmektedir. Araştırmada veri toplama yöntemi olarak anket tekniği kullanılmıştır. Araştırmanın evrenini Balıkesir ili Bandırma ilçe belediyesinde çalışan 236 personel oluştururken, araştırmanın örneklemini ise Bandırma belediyesinde çalışan 121 personel oluşturmaktadır. Yapılan korelasyon analizi sonucunda işgören sesliliği ile örgütsel bağlllığın duygusal bağlılık ve devam bağlılığı boyutları arasında istatistiksel açıdan anlamlı ilişki olduğu, işgören sesliliği ile örgütsel bağlllı̆̆ın normatif bağlllık boyutu arasında ise istatistiksel açıdan anlamlı bir ilişki olmadığı tespit edilmiştir. Yapılan regresyon analizleri sonucunda ise, işgören sesliliğinin örgütsel bağlılığın alt boyutlarından olan duygusal bağlllık ve devam bağlllığ üzerinde istatistiksel açıdan anlamlı ve pozitif bir etkisinin olduğu saptanmıştır. Araştırmanın sonunda yöneticilere öneriler ve gelecek çalışmalar için tavsiyeler yer almaktadır.
Anahtar Kelimeler

İşgören Sesliliği

Örgütsel Bağlllık

Duygusal Bağllıık

Devam Bağ lılığı

Makale Hakkında

Geliş Tarihi: 17.02.2020

Kabul Tarihi: 21.06.2021

Doi: 10.18026/cbayarsos.690044

\section{The Effect of Employee Voice on Organizational Commitment: A Research on Municipal Employees}

\begin{abstract}
The purpose of this research is to determine the effect of employee voice over organizational commitment. When the literature is examined as a reason for the research, it can be shown that there are a limited number of studies examining the relationship and influence between employee voices and organizational commitment. In this research, the survey technique was used as a data collection method. As a result of the correlation analysis, it has been determined that there is a statistically significant relationship between employee voices and organizational commitment dimensions of emotional commitment and attendance, and there is no statistically significant relationship between employee voices and the normative commitment dimension of organizational commitment. As a result of the regression analysis, it was determined that employee voice has a statistically significant and positive effect on emotional commitment and attendance commitment, which are the sub-dimensions of organizational commitment. At the end of the research, there are some suggestions.
\end{abstract}

Keywords

\section{Employee Voice \\ Organizational Commitment Emotional Commitment Continuance Commitment \\ About Article \\ Received: 17.02.2020 \\ Accepted: 21.06.2021}

Doi: 10.18026/cbayarsos.690044

\footnotetext{
a Prof. Dr., Bandırma Onyedi Eylül Üniversitesi, İşletme Bölümü, eorucu@bandirma.edu.tr, Orcid: 0000-0002-3301-7496.

b Arş. Gör, Bandırma Onyedi Eylül Üniversitesi, İşletme Bölümü, ogizlier@bandirma.edu.tr, Orcid: 0000-0002-5745-8800.

c İletişim Yazarı: ogizlier@bandirma.edu.tr

d Yüksek Lisans Öğrencisi, Bandırma Onyedi Eylül Üniversitesi, İşletme Tezli YL, gokhanorhanonay1@gmail.com, Orcid: 0000-0002-6612-6330.
} 


\section{Giriş}

Hızla değişen dünyada örgütlerin yaşamlarını sürdürebilmeleri için değişimlere ayak uydurmaları gereklidir. Örgütlerin kontrolü mümkün olmayan ve sürekli değişmekte olan diş çevreye uyum çalışmaları sırasında aldığı kararlara ve uygulamak istediği gelecek projeksiyonlarına karşı, aidiyet ve bağlılık düzeyleri düşük işgörenler tarafından direnç ve kabul etmeme gibi tepkilerin ortaya çıkması muhtemeldir. İşgörenlerin bu olumsuz tepkileri örgüt performansına olumsuz etki ederek etkinlik, verimlilik gibi konularda performans kayıplarına sebep olacaktır. Bu performans kayıplarını asgari düzeye indirmek, hatta ortadan kaldırmak adına üzerinde durulması gereken konu örgütsel bağl1lıktır. Örgütsel bağlılık üzerine yapılan çalışmalar sonucunda, örgütleri ile ilişkilerini azaltma eğiliminde olan işgörenlere yapılan örgütsel bağlılık arttırıcı çalışmaların, işgörenlerin örgütlerine olan bağlılıklarını yükselterek, işgören verimliliğini arttırdığı ve bunun sonucunda da örgüt performansının yükseldiği gözlemlenmektedir (Mowday, Porter, \& Steers, 1982).

Yine örgüt performansına etki eden önemli kavramlardan biri olan işgören sesliliğinin örgütün performansına olumlu anlamda katkı sağladığı ve örgütte olumlu bir hava sağlanmasında önemli bir yeri olduğu yapılan çalışmalarla ortaya koyulmuştur (Le Pine \& Van Dyne, 2001; Oral Ataç, 2020).

$\mathrm{Bu}$ çalışma, işgören sesliliği ile örgütsel bağlılık arasında anlamlı bir ilişkinin bulunup bulunmadığını ve işgören sesliliğinin örgütsel bağlllık ve alt boyutlarının üzerinde etkisinin olup olmadığını belirlemek amacıyla yapılmıştır. Literatür incelendiğinde, işgören sesliliği ile örgütsel bağlılık arasında yapılmış 3'ü yurtdışında (Bos, 2014; Farndale, Van Ruiten, Kelliher \& Hope-Hailey, 2011; Prasadika \& Nishanthi, 2018), 1'i yurtiçinde (Ayyıldız, 2018) olmak üzere sadece 4 çalışmaya rastlanılmıştır. Buradan hareketle, bu araştırmanın gerekçesi olarak literatürde işgören sesliliği ile örgütsel bağlılık arasında yapılmış çalışmaların yetersiz olması (özellikle ulusal literatürde) gösterilebilir. Ayrıca, bu çalışmanın belediye çalışanları üzerinde yapılmış olması, araştırmayı literatürde yapılmış çalışmalardan farklılaştırmaktadır. Çalışmada öncelikle değişkenler açıklanarak bunlarla ilgili geçmiş çalışmalara yer verilmiştir. Ardından Bandırma Belediyesi çalışanları üzerinde yapılan uygulama sonuçlarına yer verilmiştir. Sonuç bölümünde ise elde edilen bulgulara yer verilerek işletmeler ve yöneticiler için birtakım önerilerde bulunulmuştur.

\section{Kavramsal Çerçeve}

\section{İşgören Sesliliği}

Geçmişten günümüzde farklılaşan insan ihtiyaçları ve istekleri doğrultusunda işgörenlerin örgütten beklentileri de değişmektedir. İşgören sesliliği de bu beklentiler arasındadır. “Seslilik davranışı, ilk olarak 1970 yılında Hirschman tarafından sakıncalı bir durumdan kaçmak yerine durumu değiştirmek için faaliyette bulunmak olarak tanımlanmıştır. Daha net bir biçimde, örgütün işleyişinin iyileştirilmesine yardımcı olmak için fikir, öneri veya endişeleri ifade etmek olarak tanımlanabilir" (Derin, 2017; Ekrot, Rank, \& Gemünden, 2016). Diğer bir tanımlamaya göre ise işgören sesliliği, çalışanların işletmedeki işle veya örgüt iklimiyle ilgili düşünce, öneri, fikir ve problemleri ifade etme seviyesi olarak nitelendirilmiştir (Van Dyne \& LePine, 1998). Van Dyne ve LePine (1998), örgütün çevresi dinamik olduğunda ve yeni fikirlerin örgütleri sürekli geliştirme ve iyileştirme olanağı olduğunda çalışan sesliliğinin örgütler için önemli olduğunu vurgulamışlardır.

Örgütsel Bă̆lılık 
Araştırmanın değişkenlerinden örgütsel bağlılık hakkında çok sayıda farklı tanım bulunmaktadır. Bu tanımlardan konu üzerine çalışmalar yapan Meyer ve Allen (1997)'e göre örgütsel bağlılık "Çalışanın örgüte olan psikolojik yaklaşımını ifade eden ve işgören ile örgüt arasındaki ilişkiyi yansıtan, örgüt üyeliğini devam ettirme kararına yol açan psikolojik bir durumdur" (Meyer \& Allen, 1997).

\section{Örgütsel Bă̆lilı̆̆ın Alt boyutları}

\section{Duygusal Bă̆lilık}

Araştırma değişkenlerinden örgütsel bağlılığın alt boyutlarından olan duygusal bağlılık çalışanın örgütle duygusal ve psikolojik açıdan bütünleşmesini yansıtmaktadır. Duygusal bağlılığın, çalışanların örgütsel amaç ve değerleri kabullenmesini kolaylaştırdığı ve örgüt yararına olağanüstü çaba sarf etmesini içerdiği ifade edilebilir (Gül, 2002). Üyesi oldukları örgütlere duygusal bağlılıkları yüksek olan işgörenlerin örgütün çıkarları için diğer işgörenlere göre daha fazla emek ve çaba harcadığı, bu doğrultuda ellerinden geleni yaptıkları söylenebilir. Bu sebeple, örgüt yöneticileri örgütlerinde duygusal bağlllıkları yüksek çalışanları görmek isteyip duygusal bağlılıkları yüksek çalışanların sayısının artmasını arzu ederler (Uyguç \& Çımrın, 2004).

\section{Devam Bă̆glilı̆̆ı}

Araştırmanın değişkenlerinden örgütsel bağlılık alt boyutlarından bir diğeri olan devam bağlılığı, işgörenin örgütten ayrılmasının getireceği maliyetlerin farkında olup bu maliyetler sebebiyle örgütün üyesi olarak kalma isteği anlamına gelmektedir. Başka bir ifadeyle devam bağlılığı, örgütten ayrılmanın maliyetinin yüksek olacağının düşünülmesi nedeniyle duygusal olarak istenmese bile örgüt üyeliğinin sürdürülmesi durumudur. Devam bağlılı̆̆ında duyguların örgüte bağlanmada minimum seviyede rol oynadığı söylenebilir (İlsev, 1997).

\section{Normatif Băglilık}

Araştırmanın değişkenlerinden örgütsel bağlılık alt boyutlarından bir diğeri olan normatif bağl1lık, işgörenlerin örgüte karşı hissettikleri sorumluluğa ve örgütün bir parçası olduklarına dair inançlarını belirtmektedir. Normatif bağlılık, işgörenin örgüte bağlılık gösterilmesini yapılması gerekli bir görev ve sorumluluk olarak algılayarak örgüte bağlılık gösterilmesinin doğru olduğunu idrak etmesi neticesinde gelişir. Normatif bağlılık bu açıdan ahlaki süreçlerle gelişen bir bağlılık türü olduğu için duygusal ve devam bağlılıklarından oldukça farklı olduğu söylenebilir (Gül, 2002).

\section{İşgören Sesliliği ve Örgütsel Bağlılık Hakkında Yapılan Araştırmalar}

Literatürde örgütsel bağlllık ile ilgili birçok araştırma göze çarparken, işgören sesliliği konusunda ve işgören sesliliğinin örgütsel bağlllık ile ilişkisi konusunda özellikle ulusal literatürde çalışmaların azlığı dikkat çekmektedir.

Bu kısıtlı çalışmalardan biri Farndale vd. (2011) tarafından yapılan çalışmadır. İngiltere'de farklı firmalarda çalışan 2291 kişi üzerinde yapılan çalışmada, işgören sesliliğinin örgütsel bağlılık üzerinde pozitif etkisi olduğu bulunmuş. Çalışmada örgütsel bağlılık boyutlar bazında ele alınmamış, genel örgütsel bağlılık üzerinde işgören sesliliğinin etkisi incelenmiştir. Çalışmada ayrıca, işgören sesliği ile örgütsel bağlılık arasındaki ilişkide çalışanyönetici ilişkisinin ve çalışanın üst yönetime güveninin kısmi aracı etkisinin olduğu tespit edilmiştir. 
2018 yılında Prasadika ve Nishanthi tarafından yapılan çalışmada da Farndale vd. (2011)'nin yaptığı çalışmaya benzer sonuçlar elde edilmiştir. Sri Lanka'da 150 üretim firması çalışanı üzerinde yapılan çalışmada, işgören sesliliğinin örgütsel bağlllık üzerinde pozitif etkisi olduğu bulunmuştur.

Bos (2014) tarafından, işgören sesliliğinin inovatif davranışlar üzerindeki etkisinde duygusal bağlılığın aracı rolünü araştırmak üzere Hollanda'da bir firmada çalışan 183 çalışan üzerinde yapılan çalışmada ise, işgören sesliliğinin duygusal bağlılık üzerinde negatif etkisi olduğu saptanmıştır.

Ulusal literatürde işgören sesliliği ile örgütsel bağlılık değişkenlerini ele alıp inceleyen tek çalışma ise Ayyıldız (2018) tarafından yapılan yüksek lisans tez çalışmasıdır. İstanbul'da telekomünikasyon sektöründe çalışan 252 uzman ve yönetici üzerinde işgören sesliliğinin örgütsel bağlllık ve çalışan mutluluğu üzerindeki etkisini araştırmak için yapılan çalışmada, çalışanların destekleyici yönde sesliliğinin örgütsel bağlılık üzerinde pozitif etkisinin olduğu bulunmuştur.

İşgören sesliliği ile örgütsel bağlılık arasındaki ilişkiyi inceleyen çok az sayıda çalışma (Ayyıldız, 2018; Bos, 2014; Farndale vd., 2011; Prasadika \& Nishanthi, 2018) olduğu için değişkenler için ayrı ayrı yapılan çalışmalar incelenmiştir. Bu yönde, araştırmada incelenen başlıklara yakın çalışmalar seçilmiştir.

\section{Örgütsel Bă̆lılık}

Bayram (2005)’’n yaptığı çalışmada, örgütsel bağlllık ve alt boyutları incelenmiş, örgütsel bağlılığa etki eden faktörlere ve literatürdeki sinıflandırmalara değinilmiştir. Çalışmada örgütsel bağlılığın hedeflere ulaşmadaki önemi ve örgütsel bağlılıkları güçlü olan işgörenlerin görevlerini yapmada görece daha iyi olduğu ve örgütte kurdukları ilişkilerin daha uzun süreli olduğu ifade edilmiştir (Bayram, 2005).

Başka bir çalışmada, örgütsel destek ve örgütsel bağlılık arasındaki bağlantı incelenmiştir. Mobilya sektöründe çalışmakta olan 412 çalışana uygulanan anket çalışmasının sonucunda, işgörenlerin örgütsel bağlılıklarının artması sonucu performans, verim, motivasyon gibi örgütler için önemi faktörlerde de artış olacağı bulgulanmıştır (Özdevecioğlu, 2003).

Yapılan diğer bir çalışmada örgütsel adalet ve örgütsel bağlılık kavramları arasındaki ilişki incelenmiştir. 426 çalışandan elde edilen verilerin bulguları, örgütsel adalet ile örgütsel bağlılık arasında anlamlı pozitif bir ilişki olduğu yönündedir. Çalışmada, örgüt içinde adalet algısının yüksek olmasının çalışanların örgütsel bağlılıklarını arttıracağı ve buradan hareketle çalışanların performanslarının yükseleceğine değinilmiştir (Yazıcıŏlu \& Topaloğlu, 2009).

Başka bir çalışmadaki 283 anketten elde edilen verilerin ışığında örgütsel bağlılığın örgütsel vatandaşlık davranışı üzerinde pozitif bir etkiye sahip olduğu bulgularına yer verilmiştir. Çalışmada işgörenlerin duygusal bağlılıkları artış gösterdikçe daha yüksek seviyede örgütsel vatandaşlık davranışı sergiledikleri belirtilmektedir (Bolat \& Bolat, 2008).

Yapılan başka bir çalışmada örgütsel bağlılık ve örgüt iklimi arasındaki ilişki incelenmiştir. Yapılan araştırmada, örgüt iklimine etki eden örgüt içi uygulamaların işgörenler tarafından benimsenmediğinde ve işgörenlerin bu yönde beklentilerinin karşılanmaması sebebiyle bağlı oldukları örgütü seviyor olsalar da bu durumun işgörenlerin örgütsel bağlılıklarını olumsuz yönde etkilediği sonucuna ulaşılmıştır (Yüceler, 2009). 


\section{İşgören Sesliliği}

Şehitoğlu tarafından 2012 yılında yapılan çalışmada işgören sesliliği kavramı üzerinde durulmuş, sebepleri ve boyutları açıklanmıştır. Seslilik çalışmalarının arttırılması ve seslilik kavramının diğer değişkenlerle birlikte kullanılması gerektiği bu sayede işletmelerin performansı arttırıcı tedbirleri alabileceğinden bahsedilmiştir (Şehitoğlu, 2012).

Spencer 1986 yılında yaptığı çalışmada, işgören sesliliği ile çalışanı işte tutma kavramları arasındaki ilişkiyi araştırmıştır. Spencer tarafından yapılan araştırmada, çalışanların memnuniyetsizliklerini dile getirmelerinin organizasyonda kalma ihtimallerini arttırdı $\breve{g}_{1}$ sonucuna ulaşılmıştır (Spencer, 1986).

Yener tarafından 2018 yılında yapılan çalışmada işgören sesliliği, tükenmişlik sendromu ve bilgi uçurma değişkenleri arasındaki ilişki araştırılmıştır. Araştırmada örgütsel nedenlerden dolayı tükenmişlik düzeyi yüksek olan çalışanların bilgi uçurma davranışı gösterdiği sonucuna ulaşılmıştır. Araştırmada ayrıca, örgütsel bağlılık seviyesi düşük çalışanların bilgi uçurma düzeylerinin yüksek olduğu bulgulanmıştır. Bununla birlikte aynı araştırmada, örgüt içindeki işgören sesliliğinin artması sonucu oluşan psikolojik rahatlık ortamında bilgi uçurma davranışlarının azaldığı sonucuna da ulaşılmıştır (Yener, 2018).

Derin ve Demirel'in 2017 yılında yaptıkları çalışmada yöneticiye duyulan güvenin işgören sesliliği üzerindeki etkisinde psikolojik rahatlığın aracı rolü araştırılmıştır. Araştırma sonucunda yöneticiye duyulan güvenin hem psikolojik rahatlık hem de işgören sesliliği üzerinde etkisi olduğu sonucuna ulaşılmıştır (Derin \& Demirel, 2017).

Göktaş Kulualp, 2016 yılında yaptığ1 çalışmada işgören sesliliği ile bazı kişisel ve örgütsel özellikler arasındaki ilişkiyi araştırmıştır. Araştırmanın sonucunda çalışan sesliliği arttığında iş tatmininin de arttığ1 gözlemlenmiştir. Çalışmada aynı zamanda, içsel kontrol odağının artmasının işgören sesliliğini arttırdığı sonucuna ulaşılmıştır (Göktaş Kulualp, 2016).

\section{Yöntem}

\section{Araştırmanın Amacı ve Hipotezleri}

$\mathrm{Bu}$ araştırmanın amacı, işgören sesliliği ve örgütsel bağlılık arasındaki ilişkiyi belirlemek, işgören sesliliğinin örgütsel bağlılık ve alt boyutları üzerinde bir etkisinin olup olmadığını tespit etmektir. İlgili literatürde, işgören sesliliğinin örgütsel bağlılık üzerinde pozitif (Ayyıldız, 2018; Farndale vd. 2011, Prasadika \& Nishanthi, 2018) ve negatif (Bos,2014) etkisi olduğunu bulgulayan kısıtlı sayıda çalışmalar mevcuttur. Ayrıca, sosyal değişim kuramına göre, işgörenler çalıştıkları örgütleri maliyet-fayda analizine göre değerlendirip örgütten aldıkları ölçüsünde örgüt lehine tutumlar ya da davranışlar geliştirirler (Blau, 1964). Örgütlerinde kendilerini rahatça ifade edip, seslilik davranışları sergileyebilen işgörenlerin de bu çerçevede kendilerini rahatça ifade etme fırsatı veren örgütlerine karşı bağlılık gibi olumlu tutumda olabilecekleri ifade edilebilir. Bu bağlamda, yukarıda bulguları ortaya konan çalışmalar ve sosyal değişim kuramı ışığında geliştirilen hipotezler aşağıda sunulmuştur.

H1: İşgören sesliliği ile örgütsel bağlılık arasında anlamlı bir ilişki bulunmaktadır.

H2: İşgören sesliliğinin örgütsel bağllık üzerinde anlamlı bir etkisi vardır.

H2a: İşgören sesliliğinin duygusal bağlılık üzerinde anlamlı bir etkisi vardır.

H2b: İşgören sesliliğinin devam bağlılı̆̆ üzerinde anlamlı bir etkisi vardır.

H2c: İşgören sesliliğinin normatif bağlılık üzerinde anlamlı bir etkisi vardır. 


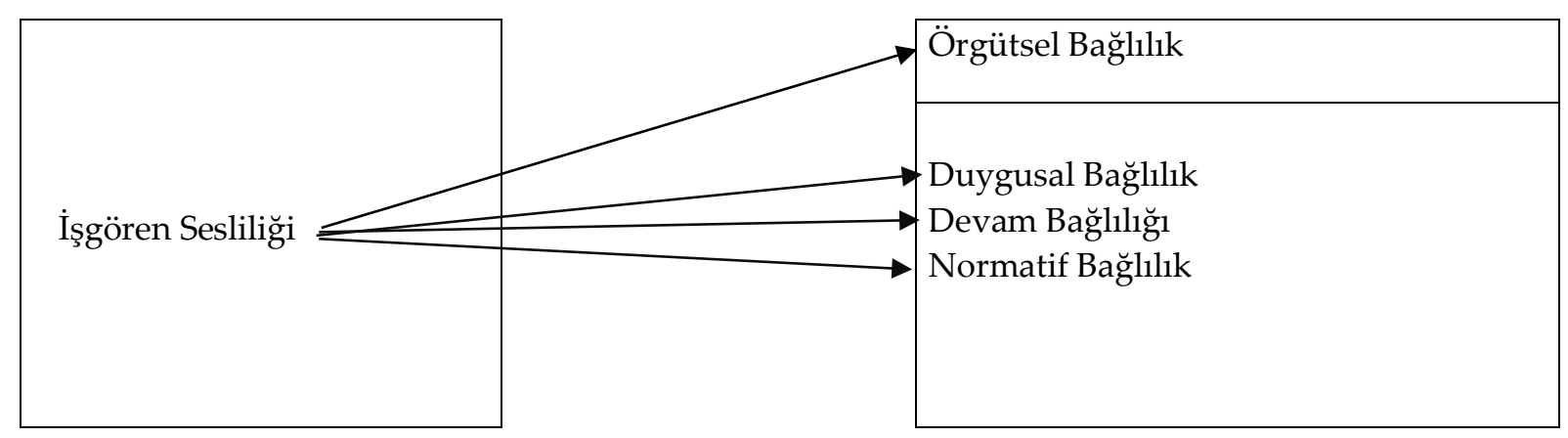

Şekil 1. Araştırma modeli

\section{Araştırmanın Evren ve Örneklemi}

$\mathrm{Bu}$ çalışmanın evreni, Balıkesir ilinin Bandırma ilçesindeki 236 Bandırma Belediyesi çalışanıdır. Çalışmanın örneklemini ise, kolayda örnekleme yöntemi ile ulaşılan Bandırma Belediyesi bünyesindeki 121 çalışan oluşturmaktadır. Yüz yüze anket uygulaması 2019 yılının Kasım ayında gerçekleştirilmiştir. Gürbüz ve Şahin (2018), örneklem hesaplama formüllerinden yola çıkarak farklı evrenler için kabul edilebilir asgari örneklem büyüklüklerini gösteren hazır tablolar hazırlamışlardır. Gürbüz ve Şahin (2018)'e göre, nicel desenli sosyal bilim araştırmaları için, \%90 güvenilirlik düzeyinde evren sayısının 250 olduğu araştırmalar için asgari örneklem büyüklügünün 97, evren sayısının 350 olduğu araştırmalar için asgari örneklem büyüklüğünün 109, evren sayısının 500 olduğu araştırmalar için asgari örneklem büyüklüğünün 121 olduğu belirlenmiştir. Buradan yola çıkarak, mevcut araştırmada 121 kişiden oluşan örneklemin evreni temsil açısından asgari düzeyde yeterli olduğu söylenebilir.

\section{Veri Toplama Yöntemi ve Araçları}

Araştırmada katılımcılara uygulanan anket iki bölüm şeklinde hazırlanmıştır. Birinci bölümde katılımcıların demografik özelliklerinin tespiti için altı soru bulunmaktadır. İkinci bölümde araştırmaya katılan çalışanların işgören sesliliğini ölçmek için 6, çalışanların örgütsel bağlılıklarını ölçmek için ise 18 soru, toplamda 24 soru bulunan iki ayrı ölçek kullanılmıştır. Ankette bulunan ölçekler ve ölçeklerdeki ifadeler 5'li Likert ölçeğe göre düzenlenmiştir. Bunlar sırası ve değeri ile şöyledir; “(1) Kesinlikle Katılmıyorum, (2) Katılmıyorum, (3) Kararsızım, (4) Katılıyorum, (5) Kesinlikle Katılıyorum"

Araştırmada işgören sesliliği değişkenini ölçmek için Van Dyne ve LePine (1998) tarafından geliştirilmiş 6 maddelik tek boyutlu işgören sesliliği (İSÖ) ölçeği kullanılmıştır. Ölçeğin Türkçe geçerliliği ve Türkçe'ye uyarlanma çalışması Arslan ve Yener (2016) tarafından yapılmıştır. Arslan ve Yener (2016), yaptıkları analizler sonucu ölçeğin Türkçe alan yazında kullanılabileceğini ifade etmişlerdir. Bireylerin kendi beyanlarına dayalı bir ölçme aracı olan işgören sesliliği (İSÖ) ölçeğinde herhangi bir ters soru yoktur (Arslan \& Yener, 2016).

Araştırmada ikinci ölçek olarak Meyer, Allen ve Smith (1993) tarafından geliştirilen, Türkçe geçerliliği Bağcı (2013) tarafından yapılmış örgütsel bağlılık ölçeği kullanılmıştır. Bu ölçeğin Türkçe soruları için, Bağcı (2013)'nın çalışmasından faydalanılmıştır. Meyer vd. (1993)'nin ve Bağ Cı (2013)'nın çalışmasında örgütsel bağlılık; duygusal bağlılık alt boyutu, devam bağl1lığ alt boyutu ve normatif bağlllık alt boyutundan oluşan üç faktör altında ele alınmıştır. Duygusal bağlılık faktörünün temelinde işgörenlerin örgüte olan bağlllık isteği ve örgütte kalma isteği araştırılırken, devam bağlılığ faktöründe işgörenin örgütte çalışmaya devam 
etme ve örgütten ayrılması halinde ortaya çıkacak problemlere katlanma seviyesi incelenmiş ve normatif bağlılık faktöründe işgörenin örgütte çalışmaya devam etmesi için gerekli olan nedenler incelenmiştir. Örgütsel Bağl1lık ölçeğinin; 1.,2.,3.,4.,5. ve 6. soruları duygusal bağlılık boyutunu, 7.,8.,9.,10.,11. ve 12. soruları devam bağl1lı̆̆1 boyutunu, 13.,14.,15.,16.,17. ve 18. soruları ise normatif bağlılık boyutunu ölçmektedir (Bağc1, 2013).

\section{Güvenirlik Testi}

Çalışanların seslilik ve örgütsel bağlllık düzeylerini ölçmek için kullanılan ankette, her iki değişken için de güvenirliği kabul edilmiş hazır ölçekler (yukarıda bahsedilmiş) kullanılmıştır. Literatür taraması yapıldığında birçok makale ve tez çalışmasında bu ölçeklerin kullanıldı̆̆ı görülmüştür.

Literatürde oldukça yaygın olan güvenilirlik ölçütü Alpha katsayısının ölçeğin güvenilir olması için en az \%70 olması gerektiği yönünde fikir birliğinin olduğu söylenebilir (Gürbüz \& Şahin, 2018). Güvenirliliği bozan ve normal dağılımı etkilediği tespit edilen ifade olmadığı için ölçekler ve ifadeler aynen değerlendirmeye alınmıştır.

Tablo 1. İşgören Sesliliği ve Örgütsel Bağlılık Ölçeklerinin Güvenirlik Analizi Bulguları

\begin{tabular}{lcc}
\hline & Soru Sayıları & Cronbach's Alpha Değerleri \\
\hline İşgören Sesliliği Ölçeği & 6 & 0,927 \\
\hline Örgütsel Bağllık Ölçeği & 18 & 0,768 \\
\hline
\end{tabular}

İşgören sesliliği ölçeği güvenirlik oranının \%92.7, örgütsel bağlllık ölçeği güvenirlik oranının ise \%76.8 bulunması, ölçeklerin yeterli düzeyde güvenilir ölçekler olduğunu ortaya koymaktadır.

\section{Normallik Testi}

Verilerin normal dağılıp dağılmadığını tespit etmek için, basıklık ve çarpıklık değerleri incelenmiş ve sonuçlar aşağıdaki "Ölçeklerin Basıklık ve Çarpıklık Değerleri" tablosunda gösterilmiştir.

Tablo 2. Ölçeklerin Basıklık ve Çarpıklık Değerleri

\begin{tabular}{lcc}
\hline & Basıklık & Çarpıklık \\
\hline İşgören Sesliliğ̈i Ölçeği & 0,822 & $-1,010$ \\
\hline Örgüt Bağlllı̆̆ı Ölçeği & 1,092 & $-0,281$ \\
\hline
\end{tabular}

Tablo 2 incelendiğinde, ölçeklerin basıklık ile çarpıklık değerlerinin $-1,5$ ve $+1,5$ aralığında olduğu görülmektedir. Buradan yola çıkarak verilerin normal dağıldığı ve parametrik testlere uygun olduğu söylenebilir (Tabachnick \& Fidell, 2012).

\section{Bulgular}


Gürbüz ve Şahin (2017)'e göre, faktör analizi 200'ün altındaki örneklemlerde doğru çalışmamaktadır (Gürbüz \& Şahin,, 2017). Bu doğrultuda, araştırmadaki örneklem sayısının 200'ün altında olmasından dolayı çalışmada faktör analizi yapılmamıştır.

\section{Demografik Değişkenlerin İstatistikleri}

Katılımcıların demografik bilgilerinin yer aldığı anket formunun birinci bölümündeki cinsiyet, yaş, medeni durum, eğitim durumu, kurumda çalışma süresi ve toplam çalışma süresi sorularının frekans dağılımlarına ilişkin tablo aşağıda sunulmuştur.

Tablo 3. Demografik Verilerin Dağılımı

\begin{tabular}{|c|c|c|c|c|c|}
\hline Cinsiyet & Frekans & $\%$ & Eğitim Durumu & Frekans & $\%$ \\
\hline & & & İlkokul & 4 & 3.3 \\
\hline Kadın & 59 & 48.8 & & & \\
\hline & & & Lise & 21 & 17.4 \\
\hline Erkek & 62 & 51.2 & & & \\
\hline Toplam & 121 & 100 & Üniversite (lisans) & 86 & 71.1 \\
\hline Yaş & Frekans & $\%$ & \multirow[t]{2}{*}{ Yüksek Lisans } & 10 & 8.3 \\
\hline $18-25$ & 4 & 3.3 & & 121 & 100 \\
\hline $26-30$ & 27 & 22.3 & Kurumda Çalışma Süresi & Frekans & $\%$ \\
\hline $31-40$ & 60 & 49.6 & 1 Yll Altı & 12 & 9.9 \\
\hline $41-50$ & 24 & 19.8 & 1-3 Yil & 13 & 10.7 \\
\hline 51 Üstü & 6 & 5 & 4-6 Yıl & 36 & 29.8 \\
\hline Toplam & 121 & 100 & 7-9 Y1l & 15 & 12.4 \\
\hline $\begin{array}{l}\text { Medeni } \\
\text { Durum }\end{array}$ & Frekans & $\%$ & 10 Yil Üstü & 45 & 37.2 \\
\hline Evli & 87 & 71.9 & Toplam & 121 & 100 \\
\hline Bekar & 34 & 28.1 & Toplam Çalışma Süresi & Frekans & $\%$ \\
\hline Toplam & 121 & 100 & $1 Y_{1}$ Alt1 & 4 & 3.3 \\
\hline & & & $1-5$ & 19 & 15.7 \\
\hline & & & $6-10$ & 32 & 26.4 \\
\hline & & & $11-15$ & 28 & 23.1 \\
\hline & & & 16 Yil Üstü & 38 & 31,4 \\
\hline & & & Toplam & 121 & 100 \\
\hline
\end{tabular}

Görüldügü üzere araştırmaya katılanların \%48.8'i temsil eden 59 kişi kadın, \%51.2'yi belirten 62 kişi ise erkeklerden oluşmaktadır. Bu katılımcıların \%3,3'ünü belirten 4 kişi 18-25 yaş 
arasında \%22,3'ünü belirten 27'si 26-30 yaş arasında, \%49,6'sını belirten 60 kişi 31-40 yaş arasında, \%19,8'ini belirten 24 kişi 41-50 yaş arasında son olarak \% $\%$ 'ini belirten 6 kişi ise 51 yaş ve üstü katılımcılardır. Ankete katılım gösterenlerin \%71.9'unu belirten 87 kişinin medeni durumu evli iken, \%28.1'ini belirten 34 kişi ise medeni durumu bekardır. Katılımcıların eğitim durumlarına bakıldığında 3.3'ünü belirten 4 kişi ilkokul, 17.4'ünü belirten 21 kişi lise,71.1'ini belirten 86 kişi üniversite ve 8.3'ünü temsil eden 10 kişi ise yüksek lisans mezunu olarak görülmektedir. Katılımcıların kurumlarında çalıştıkları sürelere bakıldığında 9.9'unu belirten 12 kişi 1 yıl altında, 10.7'sini belirten 13 kişi 1-3 yıl arası,29.8'ini belirten 36 kişi 4-6 yıl arası 12.4'ünü belirten 15 kişi 7-9 yıl arası,37.2'sini belirten 45 kişinin ise 10 yıl üstünde çalıştığ 1 görülmektedir.

Son olarak katılımcıların toplam çalışma sürelerine bakıldığında 3.3'ünü belirten 4 kişi 1 yıl altı,15.7'sini belirten 19 kişi 1-5 yıl arası, 26.4'ünü belirten 32 kişi 6-10 yıl arası, 23.1'ini belirten 28 kişi 11-15 yıl arası, 31.4'ünü belirten 38 kişi ise toplamda 16 yıldan fazla çalışma süresinin olduğu görülmektedir.

\section{Korelasyon Analizi Bulgularn}

Yapılan korelasyon analizinde değişkenler arasındaki ilişki derecesi ve yönü test edilmiştir. Korelasyon analizlerinde değişkenler arasındaki ilişki derecesi, katsayının 1'e ya da 0'a yakınlığına göre belirlenir. Yapılan analizde Pearson korelasyon analizi tercih edilmiştir. Analiz sonuçları aşağıdaki gibidir.

Tablo 4. Korelasyon Analizi Tablosu

\begin{tabular}{|c|c|c|c|c|c|c|}
\hline \multicolumn{2}{|l|}{ Değişkenler } & 1 & 2 & 3 & 4 & 5 \\
\hline \multirow{2}{*}{$\begin{array}{l}\text { İşgören Sesliliği } \\
\text { (1) }\end{array}$} & $\begin{array}{l}\text { Anlamlılık } \\
\text { Değeri }\end{array}$ & - & & & & \\
\hline & Pearson K. & 1 & & & & \\
\hline \multirow{2}{*}{$\begin{array}{l}\text { Duygusal } \\
\text { Bağlilık } \\
\text { (2) }\end{array}$} & $\begin{array}{l}\text { Anlamlilık } \\
\text { Değeri }\end{array}$ & ,000 & - & & & \\
\hline & Pearson K. &, $572^{* *}$ & 1 & & & \\
\hline \multirow{2}{*}{$\begin{array}{l}\text { Devam Bağlılığı } \\
\text { (3) }\end{array}$} & $\begin{array}{l}\text { Anlamlılık } \\
\text { Değeri }\end{array}$ & ,000 & ,000 & - & & \\
\hline & Pearson K. &, $451^{* *}$ &, $684^{* *}$ & 1 & & \\
\hline \multirow{2}{*}{$\begin{array}{l}\text { Normatif Bağlılık } \\
\text { (4) }\end{array}$} & $\begin{array}{l}\text { Anlamlılık } \\
\text { Değeri }\end{array}$ & ,099 & ,844 & ,504 & - & \\
\hline & Pearson K. &,- 151 &,- 018 & ,061 & 1 & \\
\hline \multirow{2}{*}{$\begin{array}{l}\text { Örgütsel Bağlılık } \\
\text { (5) }\end{array}$} & $\begin{array}{l}\text { Anlamlilık } \\
\text { Değeri }\end{array}$ & ,000 & ,000 & , 000 & , 000 & - \\
\hline & Pearson K. &, $424^{* *}$ & ,798** &, $845^{* *}$ & $467^{* *}$ & 1 \\
\hline
\end{tabular}

Araştırmaya katılan çalışanların işgören sesliliği ile örgütsel bağlılık arasındaki ilişkiyi ölçmek için yapılan analizde, işgören sesliliği ile örgütsel bağlılık arasında anlamlı pozitif bir ilişki olduğu görülmektedir (H1 Kabul). Bununla birlikte, işgören sesliliği ile örgütsel bağlılı̆̆ın duygusal ve devam bağlılığı alt boyutları arasında anlamlı ve pozitif bir ilişki olduğu, işgören 
sesliliği ile normatif bağlılık arasında anlamlı bir ilişki olmadığ görülmektedir. İşgören sesliliği ile örgütsel bağlılığın alt boyutları arasındaki ilişkinin gücü bakımından, güçlüden zayıf ilişkiye doğru örgütsel bağlılık alt boyutlarının duygusal bağlılık $\left(, 572^{* *}\right)$ ve devam bağl1lığ $\left(, 451^{* *}\right)$ şeklinde sıralandığı görülmektedir.

\section{Regresyon Analizi Bulguları}

$\mathrm{Bu}$ bölümde hipotezlerin testine ilişkin regresyon analizi sonuçlarına yer verilmiştir. Analizlerde anlamlılık sonuçlarını gösteren ANOVA a tablosuna yer verilmiştir. ANOVA ${ }^{a}$ tablosunda modelin anlamlılığı değerlendirilip, bu tablo bağımlı değişkendeki varyansın model tarafından ne kadar iyi açıklandığını gösterir. Tablodaki anlamlılık değeri (sig.) 0,05 değerinden ne kadar küçük olursa, regresyon modelinin bağımlı değişkeni o kadar iyi açıkladığı ifade edilebilir (Gürbüz \& Şahin, 2018).

Tablo 5. İşgören Sesliliği ve Örgütsel Bağlılık Arasında Kurulan Regresyon Modeli Anova Sonuçları

ANOVA $^{\mathrm{a}}$

\begin{tabular}{|c|c|c|c|c|c|}
\hline Model & $\mathrm{R}^{2}$ Toplamları & $\mathrm{df}$ & $\begin{array}{c}\text { Ort. } \\
\text { Kare }\end{array}$ & $\mathrm{F}$ & Sig. \\
\hline $\begin{array}{c}\text { 1. Gruplar } \\
\text { Arası }\end{array}$ & 5,135 & 1 & & & \\
\hline & & & 5,135 & 26,068 &, $000^{\mathrm{b}}$ \\
\hline Grup İici & 23,439 & 119 &, 197 & & \\
& & & & & \\
Toplam & 28,574 & 120 & & & \\
\hline
\end{tabular}

a) Bağımlı Değişken: Örgütsel Bağlılık

b) Yordayıcılar: (Sabit), İşgören Sesliliği

Tablo 5.1. İşgören Sesliliği ve Örgütsel Bağlılık Arasında Kurulan Regresyon Analizi Sonuçları

\begin{tabular}{|c|c|c|c|c|c|}
\hline & \multicolumn{2}{|c|}{$\begin{array}{c}\text { Standartlaştırılmamış } \\
\text { Katsayılar }\end{array}$} & Std. Katsayılar & \\
\cline { 2 - 4 } Model & B & Std. Hata & Beta & t & Sig. \\
\hline 1 (Sabit) & 2,324 &, 172 & & 13,549 &, 000 \\
\hline $\begin{array}{c}\text { İ̧gören } \\
\text { Sesliliği }\end{array}$ &, 233 &, 046 &, 424 & 5,106 &, 000 \\
\hline
\end{tabular}

a) Bağımlı Değişken: Örgütsel Bağlılık

Tablo 5'teki ANOVA testi sonuçları incelendiğinde oluşturulan regresyon modelinin anlamlı olduğu görülmekte (F 26,068; Sig p<0,05), katsayılar tablosundaki B değerlerine bakıldı̆̆ında ise işgören sesliliğindeki bir birimlik yükselişin örgütsel bağlılığı \%23,3 oranında arttırdığ 
söylenebilir. Yine analiz sonuçlarına bakıldığında işgören sesliliğinin örgütsel bağlılığ1 anlamlı düzeyde etkilediği görülmüştür. Bu çerçevede $\mathrm{H} 2$ hipotezi kabul edilmiştir.

Tablo 6. İşgören Sesliliği ve Duygusal Bağllık Arasında Kurulan Regresyon Modeli Anova Sonuçları

ANOVA ${ }^{a}$

\begin{tabular}{|c|c|c|c|c|c|}
\hline Model & $\mathrm{R}^{2}$ Toplamları & $\mathrm{df}$ & $\begin{array}{c}\text { Ort. } \\
\text { Kare }\end{array}$ & $\mathrm{F}$ & Sig. \\
\hline $\begin{array}{c}\text { 1.Gruplar } \\
\text { Arası }\end{array}$ & 18,173 & 1 & 18,173 & 57,949 &, $000^{\mathrm{b}}$ \\
\hline & & & & & \\
Grup İici & 37,318 & 119 &, 314 & & \\
\hline & & & & & \\
Toplam & 55,490 & 120 & & & \\
\hline
\end{tabular}

a) Bağımlı Değişken: Duygusal Bağlılık

b) Yordayıcılar: (Sabit), İsgören Sesliliği

Tablo 6.1. İşgören Sesliliği ve Duygusal Bağlılık Arasında Kurulan Regresyon Analizi Sonuçları

\begin{tabular}{|c|c|c|c|c|c|}
\hline & \multicolumn{2}{|c|}{$\begin{array}{c}\text { Standartlaştırılmamış } \\
\text { Katsayılar }\end{array}$} & Std. Katsayılar & & \\
\cline { 2 - 3 } Model & B & Std. Hata & Beta & t & Sig. \\
\hline 1 (Sabit) & 1,637 &, 216 & & 7,563 &, 000 \\
\hline $\begin{array}{c}\text { İşgören } \\
\text { Sesliliği }\end{array}$ &, 439 & 0,58 &, 572 & 7,612 &, 000 \\
\hline
\end{tabular}

a) Bağımlı Değişken: Duygusal Bağlılık

Tablo 6' daki ANOVA testi sonuçları incelendiğinde oluşturulan regresyon modelinin anlamlı olduğu görülmekte (F 57,949; Sig p<0,05), katsayılar tablosundaki B değerlerine bakıldığında ise işgören sesliliğindeki bir birimlik yükselişin duygusal bağlılığ $\% 43,9$ oranında arttırdığını söylenebilir. Yine analiz sonuçlarına bakıldığında işgören sesliliğinin duygusal bağl1lı̆̆ anlamlı düzeyde etkilediği görülmüştür. Bu çerçevede $\mathrm{H} 2$ a hipotezi kabul edilmiştir.

Tablo 7. İşgören Sesliliği ve Devam Bağlılığı Arasında Kurulan Regresyon Modeli Anova Sonuçları

ANOVA $^{a}$ 


\begin{tabular}{|c|c|c|c|c|c|}
\hline Model & $\mathrm{R}^{2}$ Toplamları & $\mathrm{df}$ & $\begin{array}{c}\text { Ort. } \\
\text { Kare }\end{array}$ & $\mathrm{F}$ & Sig. \\
\hline $\begin{array}{c}\text { 1.Gruplar } \\
\text { Arası }\end{array}$ & 13,029 & 1 & 13,029 & 30,321 &, $000^{\mathrm{b}}$ \\
\hline & & 119 &, 430 & & \\
Grup İici & 51,134 & & & & \\
\hline & & 120 & & & \\
\hline
\end{tabular}

a) Bağımlı Değişken: Devam Bağlılı̆̆1

b) Yordayıcılar: (Sabit), İşgören Sesliliği

Tablo 7.1. İşgören Sesliliği ve Devam Bağl1lığı Arasında Kurulan Regresyon Analizi Sonuçları

\begin{tabular}{|c|c|c|c|c|c|}
\hline & \multicolumn{2}{|c|}{$\begin{array}{c}\text { Standartlaştırılmamış } \\
\text { Katsayılar }\end{array}$} & Std. Katsayılar & \\
\cline { 2 - 3 } Model & $\mathrm{B}$ & Std. Hata & Beta & $\mathrm{t}$ & Sig. \\
\hline 1 (Sabit) & 1,639 &, 253 & & 6,467 &, 000 \\
\hline $\begin{array}{c}\text { İşgören } \\
\text { Sesliliği }\end{array}$ &, 371 &, 067 &, 451 & 5,506 &, 000 \\
\hline
\end{tabular}

a) Bağımlı Değişken: Devam Bağlılı̆̆1

Tablo 7'deki ANOVA testi sonuçları incelendiğinde oluşturulan regresyon modelinin anlamlı olduğu görülmekte (F 30,321; Sig p<0,05), katsayılar tablosundaki B değerlerine bakıldığında ise işgören sesliliğindeki bir birimlik yükselişin devam bağlılığını \%37,1 oranında arttırdığını söylenebilir. Yine analiz sonuçlarına bakıldığında işgören sesliliğinin devam bağlılığını anlamlı düzeyde etkilediği görülmüştür. Bu çerçevede $\mathrm{H} 2$ b hipotezi kabul edilmiştir.

Tablo 8. İşgören Sesliliği ve Normatif Bağlılık Arasında Kurulan Regresyon Modeli Anova Sonuçları

\section{ANOVA $^{\mathrm{a}}$}




\begin{tabular}{|c|c|c|c|c|c|}
\hline Model & $\mathrm{R}^{2}$ Toplamlar & $\mathrm{df}$ & $\begin{array}{c}\text { Ort. } \\
\text { Kare }\end{array}$ & $\mathrm{F}$ & Sig. \\
\hline $\begin{array}{c}\text { 1.Gruplar } \\
\text { Arası }\end{array}$ & 1,155 & 1 & 1,115 & 2,769 & , $^{\text {. }}$ \\
\hline Grup İçi & 49,624 & 119 &, 417 & & \\
\hline Toplam & 50,779 & 120 & & & \\
\hline
\end{tabular}

a) Bağımlı Değişken: Normatif Bağlılık

b) Yordayıcılar: (Sabit), İşgören Sesliliği

Tablo 8.1. İşgören Sesliliği ve Normatif Bağlılık Arasında Kurulan Regresyon Analizi Sonuçları

\begin{tabular}{|c|c|c|c|c|c|}
\hline & \multicolumn{2}{|c|}{$\begin{array}{c}\text { Standartlaştırılmamış } \\
\text { Katsayılar }\end{array}$} & Std. Katsayılar & & \\
\cline { 2 - 3 } Model & B & Std. Hata & Beta & t & Sig. \\
\hline & 3,697 &, 250 & & 14,812 &, 000 \\
\hline $\begin{array}{c}\text { İşgören } \\
\text { Sesliliği }\end{array}$ &,- 111 &, 066 &,- 151 & $-1,664$ &, 099 \\
\hline
\end{tabular}

a) Bağımlı Değişken: Normatif Bağlılık

Tablo 8'deki ANOVA testi sonuçları incelendiğinde işgören sesliliği ve normatif bağlllık arasında oluşturulan regresyon modelinin anlamlı olmadığı ve dolayısıyla işgören sesliliğinin örgütsel bağlılığ1 anlamlı düzeyde etkilemediği görülmüştür (F 2,769; Sig p>0,05). Bu çerçevede araştırmadaki $\mathrm{H} 2$ chipotezinin desteklenmediği söylenebilir.

\section{Tartışma, Sonuç ve Öneriler}

$\mathrm{Bu}$ araştırma işgören sesliliğinin örgütsel bağlılığa etkisini incelemek amacıyla Bandırma İlçe Belediyesinin 121 çalışanına uygulanarak gerçekleştirilmiştir. Araştırmada elde edilen verilerle çeşitli analizler yapılmış, bu analizler vasıtasıyla birtakım çıkarımlar yapılmıştır. Yapılan korelasyon analizi sonucunda işgören sesliliği ile örgütsel bağlılığın duygusal bağlılık ve devam bağlılığı boyutları arasında istatistiksel açıdan anlamlı pozitif ilişki olduğu, işgören sesliliği ile örgütsel bağlılığın normatif bağlılık boyutu arasında ise istatistiksel açıdan anlamlı bir ilişki olmadığı tespit edilmiştir. Yapılan regresyon analizleri sonucunda ise, işgören sesliliğinin örgütsel bağlılık (boyutlardan bağımsız, genel) üzerinde ve örgütsel bağlılığın alt boyutlarından olan duygusal bağlılık ve devam bağllığı üzerinde istatistiksel açıdan anlamlı ve pozitif bir etkisinin olduğu saptanmıştır.

Bu araştırmanın bulgularının, literatürde Farndale vd. (2011) ve Prasadika ve Nishanthi (2018) tarafından yapılan çalışmalarda elde edilen işgören sesliliğinin örgütsel bağlılık (genel örgütsel bağlllık) üzerinde pozitif etkisinin olduğu bulgusuyla örtüştüğü söylenebilir. 
Bununla birlikte, Ayyıldız (2018) tarafından yapılan çalışmada ise işgörenlerin destekleyici yönde sesliliğinin örgütsel bağlllık üzerinde pozitif etkisinin olduğu bulunmuştur. Bu yönden de mevcut araştırma bulgularının Ayyıldız (2018) tarafından yapılan çalışmayla tutarlılık gösterdiği ifade edilebilir. Ancak burada dikkat edilmesi gereken husus, işgörenlerin seslilik davranışlarının destekleyici tarzda olmasıdır. Ayyıldız (2018)'ın çalışmasında, yalnızca destekleyici yönde işgören sesliliğinin örgütsel bağlılığı arttırdığı, savunmacı ve yıkıcı yönde gelişen işgören sesliliğinin ise örgütsel bağlılık üzerinde etkisinin olmadığı bulgulanmıştır. Diğer yandan, Bos (2014) tarafından yapılan çalışmada, işgören sesliliğinin duygusal bağlılık üzerinde negatif etkisinin olduğu bulunmuştur. Mevcut araştırmda ise, işgören sesliliğinin duygusal bağlılık üzerinde pozitif etkisinin olduğu bulunmuştur. Bu açıdan ise, bu araştırmanın bulgularının Bos (2014) tarafından yapılan çalışmanın bulgularıyla örtüşmediği söylenebilir.

Örgütlerin mevcut zorlu rekabet ortamında rakiplerine üstünlük sağlamaları için gerekli olan en önemli kaynaklardan biri olan nitelikli insan kaynağının örgüte olan bağlılıklarının arttırılması için yapılacak çalışmaların ne kadar gerekli olduğu, bu kaynağa yapılan yatırımın rekabet gücü ve katma değer olarak geri dönüşünün olacağını ifade etmek mümkündür (Çakınberk, Derin, \& Demirel, 2011). Hızla değişen dünyada insan istekleri de örgüt içi beklentiler bağlamında hızla değişmektedir. Günümüz iş dünyasında nitelikli işgörenlerin örgütsel bağlılıklarını sağlamak ve arttırmak sadece maddiyata dayalı ödüllendirme sistemleri ile mümkün olmamaktadır. Örgüt yöneticilerinin işgörenlerin bağlılıklarını sağlama ve arttırma yönündeki çalışmalarının zayıf olması sonucunda rekabet avantajı oluşturabilecek ve katma değer sağlayabilecek nitelikli işgörenin başka örgütlerde çalışmayı tercih ettikleri görülmektedir (Özdevecioğlu, 2003). Bu bağlamda, örgütte işgören sesliliğini arttırmaya yönelik çalışmalar yapılmasının, işletmeler için mevcut zorlu iş ve rekabet ortamında hayati öneme sahip olan nitelikli işgörenlerin örgüte olan bağl1lıklarını arttıracağı ve bunun sonucunda rakiplere karşı üstünlük sağlanacağ işgören sesliliğini arttırmaya yönelik faaliyetlerde bulunmaları, işgörenlere görüş, öneri ve tavsiyelerini rahatlıkla dile getirebilecekleri pozitif çalışma ortamı yaratmaları tavsiye edilebilir.

Araştırmanın kısıtları göz önüne alındığında gelecek araştırmacılara birtakım tavsiyelerde bulunmak yararlı olacaktır. Araştırmanın en büyük kısıtı, örneklem sayısıdır. Gelecekteki araştırmacılar daha büyük örneklem sayısına ulaşarak araştırmadaki model doğrultusunda araştırma tasarlayabilirler. İşgören sesliliğinin örgütsel bağlılık üzerindeki etkisi araştırılırken araştırma modeline demografik değişkenler de dahil edilip daha detaylı bulgulara ulaşılabilir, işgörenlerin seslilik davranışlarının demografik özelliklere göre farklılaşıp farklılaşmadığ tespit edilebilir. Ayrıca işgören sesliliği ve örgüt bağlılı̆̆ı arasındaki ilişki incelenirken işten ayrılma niyeti, örgüt iklimi, mobbing gibi değişkenler de bu ilişkiye dahil edilip aralarındaki ilişkiler incelenerek araştırmaya farklı bir boyut kazandırılabilir. 


\section{Kaynakça}

Arslan , A., \& Yener, S. (2016). İşgören sesliliği ölçeğinin türkçe'ye uyarlanması çalışması. Yönetim ve Ekonomi Araştırmaları Dergisi, 14(1), 173-191.

Ayyıldız, F. N. (2018). Çalışan Sesinin, Örgüte Bă̆hlı̆̆a ve Çalışan Mutluluğuna Etkisi (Yüksek Lisans Tezi, Bahçeşehir Üniversitesi Sosyal Bilimler Enstitüsü, İstanbul).

Bağ cl, Z. (2013). Çalışanların örgütsel adalet algılarının örgütsel bağlllıkları üzerindeki etkisi: Tekstil sektöründe bir inceleme. Uluslararası Yönetim İktisat ve İşletme Dergisi, 9(19), 163-184.

Bayram, L. (2005). Yönetimde yeni bir paradigma: Örgütsel bağl1lık. Sayıştay Dergisi, 16(59), $125-139$.

Blau, P.M. (1964). Exchange and Power In Social Life. New Yrok: Wiley.

Bolat, O. İ., \& Bolat, T. (2008). Otel işletmelerinde örgütsel bağlllık ve örgütsel vatandaşlık davranışı ilişkisi. Balıkesir Üniversitesi Sosyal Bilimler Enstitüsü Dergisi, 11(19), 75-94.

Bos, B. (2014). The Effect Of Employee Voice On Innovative Behavior, Mediated By Affective Commitment (Master's thesis, University of Twente).

Çakınberk, A., Derin, N., \& Demirel, E. T. (2011). Vizyoner Liderlik Işı̆̆ında Örgütsel Bağlılık (s. 84). Içinde. Sivas: Asitan Yayıncılık.

Derin, N. (2017). İşyerinde kişiler arası güven ile işgören sesliliği arasındaki ilişkide psikolojik rahatlığın aracılık rolü. Yönetim Bilimleri Dergisi, 15(30), 51-68.

Derin, N., \& Demirel, E. T. (2017). Yöneticiye duyulan güvenin işgören sesliliği üzerindeki etkisinde psikolojik rahatlığın aracı rolü. International Social Sciences and Humanities Berlin Conference.

Ekrot, B., Rank, J., \& Gemünden, H. G. (2016). Antecedents of project managers' voice behavior: The moderating effect of organization-based self-esteem and affective organizational commitment. International Journal of Project Management, 34(6), 1028-1042.

Farndale, E., Van Ruiten, J., Kelliher, C., \& Hope-Hailey, V. (2011). The influence of perceived employee voice on organizational commitment: An exchange perspective. Human Resource Management, 50(1), 113-129.

Göktaş Kulualp, H. (2016). çalışan sesliliği ile bazı kişisel ve örgütsel özellikler arasındaki ilişkinin belirlenmesi: Öğretim elemanları üzerime bir araştırma. Ege Akademik Bakış, 16(4), 745-761.

Gül, H. (2002). Örgütsel bağlılık yaklaşımlarının mukayesesi ve değerlendirmesi. Ege Akademik Bakış, 2(1), 37-56.

Gürbüz, S., \& Şahin, F. (2017). Sosyal Bilimlerde Araştırma Yöntemleri. Ankara: Seçkin Yayıncılık.

Gürbüz, S., \& Şahin, F. (2018). Sosyal Bilimlerde Araştırma Yöntemleri Felsesfe-Yöntem-Analiz. Ankara: Seçkin Yayıncılık.

İlsev, A. (1997). Örgütsel Bă̆lllık: Hizmet Sektöründe Bir Araştırma. (Yüksek Lisans Tezi, Hacettepe Üniversitesi, Ankara). 
LePine, J. A., \& Van Dyne, L. (2001). Voice and cooperative behavior as contrasting forms of contextual performance: Evidence of differential relationships with big five personality characteristics and cognitive ability. Journal of Applied Psychology, 86(2), 326-336.

Meyer, J. P., \& Allen, N. J. (1997). Commitment in the Workplace: Theory, Research, and Application. SAGE Publications Inc.

Meyer, J. P., Allen, N. J., \& Smith, C. (1993). Commitment to organizations and occupations: extension and test of a three-component conceptualization. Journal of Applied Psychology, $78(4), 538-551$.

Mowday, R. T., Porter, L. W., \& Steers, R. T. (1982). Employee-Organization Linkages: The Psychology of Commitment, Absenteeism, and Turnover. New York: Academic Press Inc.

Oral Ataç, L. (2020). Çalışan sesliliğinin öncülleri ve sonuçları: Türkiye örnekleminde gerçekleştirilen araştırmalar bağlamında ilgili yazının genel değerlendirmesi ve bir metaanaliz çalışması. İşletme Araştırmaları Dergisi, 12 (2), 1739-1755.

Özdevecioğlu, M. (2003). Algılanan örgütsel destek ile örgütsel bağl1lık arasındaki ilişkilerin belirlenmesine yönelik bir araştırma. Dokuz Eylül Üniversitesi İktisadi İdari Bilimler Fakültesi Dergisi, 18(2), 113-130.

Prasadika, G.H. H. P., \& Nishanthi, H. M. (2018). Perceived employee voice and organizational commitment: A case of Sri Lanka. Asian Journal of Empirical Research, 8(9), 330-341.

Spencer, D. G. (1986). Employee voice and employee retention. Academy of Management Journal, 29(3), 488-502.

Şehitoğlu, Y. (2012). İşgören sesliliği, nedenleri ve boyutları: Teorik bir çerçeve.. Karadeniz Teknik Üniversitesi Sosyal Bilimler Dergisi, (4), 27-38.

Tabachnick, B. G., \& Fidell, L. S. (2012). Using multivariate statistics 6th edition. Boston: Pearson.

Uyguç, N., \& Çımrın, D. (2004). Deü araştırma ve uygulama hastanesi merkez laboratuarı çalışanlarının örgüte bağlılıklarını ve işten ayrılma niyetlerini etkileyen faktörler. Dokuz Eylül Üniversitesi İktisadi İdari Bilimler Fakültesi Dergisi, 19(1), 91-99.

Van Dyne, L., \& LePine, J. A. (1998). Helping and voice extra-role behaviors: Evidence of construct and predictive validity. Academy of Management Journal, 41(1), 108-119.

Yazıcıoğlu , ̇̇., \& Topaloğlu, I. G. (2009). Örgütsel adalet ve bağlilik ilişkisi: konaklama işletmelerinde bir uygulama. İşletme Araştırmaları Dergisi, 1(1), 3-16.

Yener, S. (2018). İşgören sesliliğinin tükenmişlik ve bilgi uçurma arasındaki ilişkide düzenleyici rolü. Yönetim Bilimleri Dergisi, 16(31), 217-236.

Yüceler, A. (2009). Örgütsel bağlılık ve örgüt iklimi ilişkisi: teorik ve uygulamalı bir çalışma. Selçuk Üniversitesi Sosyal Bilimler Enstitüsü Dergisi, (22), 445-458. 